\title{
Phenomena, Poiēsis, and Performance Profiling: Temporal-Textual Emphasis and Creative Process Analysis in Turandot at the Metropolitan Opera
}

\author{
JOSHUA NEUMANN [1] \\ University of Florida
}

\begin{abstract}
Amidst discussions regarding the nature of a musical work, tensions within and between score- and performance-based approaches often increase ideological entrenchment. Opera's textual and visual elements, along with its inherently social nature, both simultaneously complicate understanding of a work's nature and provide interdisciplinary analytical inroads. Analysis of operatic performance faces challenges of how to interrogate onstage musical behaviors, and how they relate to both dramatic narrative and an opera's identity. This article applies Martin Heidegger's dichotomy of technē and poiēsis to relationships between scores, performances, and works, characterizing works as conceptual, and scores and performances as tangible embodiments. Opera scholarship relies primarily upon scores, creating a lacuna of sound-based examinations. Adapting analyses developed in CHARM's "Mazurka Project," this essay incorporates textual considerations into tempo hierarchy as a means of asserting each performance's nuanced uniqueness and thus provides a window into performers' creative processes. Interviews with the performers considered in this study confirmed postulations derived from analyzing temporal-textual emphases. This approach is adaptable to other expressive elements employed in creating a role onstage. In addition to the hybrid empirical-hermeneutic application, the datasets created in this approach could be valuable as ground truth in machine learning applications.
\end{abstract}

Submitted 2017 April 12; accepted 2017 July 26.

KEYWORDS: opera, technology theory, performance, audio analysis, tempo hierarchy

\section{INTRODUCTION: RETHINKING MUSICAL OBJECTS}

"Rather than trying to change directly the language on music, it would be better to change the musical object itself, as it presents itself to discourse.”

MUSICAL activities, especially operatic ones, are inherently social, with performance being the primary interface between artistic producers and consumers (Becker, 1982). [2] All practice involves experience in one way or another; all products resulting from operatic practice are therefore phenomena ready for consumption and analysis. The score and performance are two of the most significant components of any musical work, and yet neither alone can constitute the entirety of the work itself, nor can one attempt or claim to understand the entirety of a work by focusing solely on one or the other. As such, performance analysis is an essential component of understanding any work. The added visual and textual domains for operatic works require multi-modal consideration, and while scholars in music, literature, theatre studies, etc. have addressed them, a paucity of analytical attention to operatic performance endures. One possible interpretation of this imbalance is that performance remains, in the eyes of some musicologists, a lesser mode of creativity in authorship than composition. Sergio Durante stipulates, however, that considering singers' actions and their impact on opera "is such a natural part of any history [of it] that it needs no justification" (Durante, 1998, p. 345). This reality highlights the importance of studying singers and what they do on stage for a more comprehensive understanding of opera. Until recently, notational encoding has formed the basis for scholars' 
focus on performance, resulting in text-based, rather than sound-based analysis, often prioritizing theorists and musicologists and their analyses over performers and their insights.

Nicholas Cook (1999) assessed the then-prevailing and still-persevering generative view of score analysis as an impetus for performance (page-to-stage). He asserted that without considering either the inverse possibility (stage-to-page) or the exclusionary approach (stage-to-stage) when understanding a musical work, scholars, willingly or not, perpetuate a dichotomous paradigm when instead a dialogic paradigm is a better apparatus (p. 245). Approaches that prioritize either score or performance examine components of operatic (and musical) analysis at the cost of examining how performers realize the information of a score, and vice-versa. John Rink (2002), echoing many of Cook's ideas, offered a variety of examples of how performers analyze music in preparation for performance, which both supplemented conceptions of analysis and elevated contributions from performers to parallel those of scholars. Rink concludes his argument with the reminder that “...it is important not to elevate [analysis] above the performance it gives rise to, or to use it as a means of subjugating or shackling musicians” (p. 56). Analysis was, for Rink in 2002, a means of describing what happens in a musical work, both in score and performance.

Performance analysis as a descriptive practice has been a funded focus by the AHRC in the forms of the Centre for the History and Analysis of Recorded Music (CHARM, 2004-2009) and the Centre for Musical Performance as Creative Practice (CMPCP, 2009-2014), and has increasingly relied upon empirical methodologies. As scholars continue to develop means of understanding performance practices with increasing precision, the possibility of ascertaining the unique identity of each performance increases, and discerning performance traditions precisely becomes more feasible. [3] Opera performances are, simultaneously, products of experiences and accumulations of musical phenomena, including: tempo, phrasing, pitch relationships, breathing, rhythm, dynamics, articulation, and diction. Sounded musical phenomena affect how performers and consumers perceive musical works. This study focuses on only one of these expressive components - tempo - in relationship to the musical and textual structure of both score and performance. Tempo analysis reveals temporal-textual emphases, which this article posits as a substantial means of understanding individual artists' creative processes in operatic performance. By eventually documenting all these components together, one can construct a performance profile of the relationship between the operatic musical-dramatic text and singers' expressive palette.

While creativity conveys a variety of connotations, this article adopts a view of creativity akin to that with which Eric Clarke (2012) began his essay, "Creativity in performance": "Every musical performance is unavoidably 'creative' in the sense that if the analysis is sufficiently fine-grained it is bound to differ from every other performance in some way, somewhere” (p. 17). In this sense then, authoring a work in a form or manner that has not existed before is creative practice; both composers and performers are thus creators of a musical work. While Clarke is somewhat dismissive of the conceptual weight of this assertion, creativity in one sense is to bring into being that which has not existed before. Variances in processes and products result from human beings' inability to mechanically reproduce musical performances, compared to recordings, piano rolls, and other such technologies. This article rests, in part, on the premise that variations in performance construct unique identities for each performance, and that the nuances of these identities, at least for texted music, can provide a basis for understanding the dramatic interpretation of a role a singer portrays on a given occasion.

Beginning with a phenomenological and philosophical discussion of musical works enables a richer understanding of the analytical method and its results, as well as a merging of theoretical considerations and empirical findings. The relationship between performed music and perception reflects phenomenology's central tenet: reality results from perceptions of experiences in human consciousness and not from anything independent of that consciousness. Phenomenology, conceived as relating empirical observations of phenomena to each other, offers an appropriate starting point for analyzing opera; it opens an empirical space to understand those practices and behaviors that constitute a performance, construct a tradition, and shape its practitioners' and consumers' perceptions. This article responds to Roland Barthes's exhortation to fashion a new musical object for discourse by combining the analysis of the musical text with that of its performances and what performers do onstage, and by further adapting and extending empirical methods to achieve this aim. 


\section{SCORES, PERFORMANCES, AND WORKS}

\section{Legal Status of Operatic Scores and Performances at Emergence of Film}

Theoretical concepts regarding the relationship between (and natures of) scores and performances emerged in a decidedly concrete way in the first decade of the twentieth century. The dual modality of encountering a musical work did not escape Italian publishing magnate Giulio Ricordi, who in 1906 called an emergency board meeting of his publishing firm, the Casa Ricordi. The recent emergence of motion pictures and its possible effects on the firm's business interests was a pressing topic of conversation. With insight predating the emergence of Alan Crosland's The Jazz Singer (1927) by more than 20 years, Ricordi anticipated that film would eventually replace opera in the social sphere. [4]

Ricordi's fear of losing profits from opera performance led to his objections about the reproduction of the sounds of operas for which his firm held copyrights. On one occasion, no later than early 1906, he discovered that someone associated with the copyright collection agency Società Italiana degli Autori had not consulted him before showing a moving picture of portions of Giuseppe Verdi's Otello (the rights of which Ricordi held) in Rome. Because this was still in the 'silent film' era (before 1927's The Jazz Singer), a recording of Francesco Tamagno singing music from those scenes accompanied the showing. Incensed, Ricordi wrote to the Società, demanding that they fulfill one of their aims: protecting performances of written works, and by extension, reproductions of performances: "So if your company believes that it should protect the performance of pieces of works with phonographs that can be given in public, do it.” (Ricordi, 1906). [5]

This episode led the Ricordi company to invoke the dual Italian legal protections applicable to artistic works: diritto d'edizione to protect publishing, reproducing, and selling of printed works, and diritto di rappresentazione, to protect the right to authorize performances of a work (Thomas, 2015). The Italian legal code that Casa Ricordi invoked managed to reserve the right to grant or deny permission for any performance of an opera within the first forty years of its composition. Ricordi's application of this code included Verdi's works from Aida onward, and all of Giacomo Puccini's oeuvre (Thomas, 2015). Ricordi's legal maneuvering in response to cinema and the reproduction of operatic scores and performances appears to reflect surface-level fears about his immediate and future pecuniary realities. It also reveals his conception of the nature of an operatic work: the art form's multiple experiential modalities are in fact phenomena pertaining to a work, and, moreover, these modalities play a critical role in revealing a work.

\section{Phenomenology and Technology}

Decades later, building on Edmund Husserl, Martin Heidegger, in both Sein un Zeit (Being and Time) and "The Question Concerning Technology," examined the emergent technological world of the mid-twentieth century. [6] For him, "technology is a way of revealing" because it is "that which belongs to techne," which consists of the skills and practices of a craftsman-i.e. the work of hands-along with "the arts of the mind and the fine arts. Thus, technē belongs to bringing-forth, to poiessis; it is something poietic" (Heidegger, 1977, p. 13). Written language is perhaps the most basic form of technology:

Writing is a 'machine' to supplement both the fallible and limited nature of our memory (it stores information over time) and our bodies over space (it carries information over distances). So it's not so much that we humans made technology: technology also made us. As we write, so writing makes us. It is technology that allows us history, as a recorded past and so a present, and so, perhaps a future. So to think about technology, and changes in technology, is to think about the very core of what we, as a species, are and about how we are changing. As we change technology, we change ourselves (Eaglestone, 2013, p. 87).

Technology is thus not an invention that exists in isolation from its creators, but in a broader context of social currents, intellectual movements and cultural products. Mark Schubin has shown such bi-directional influence in his study of the relationship between technology and opera. [7] 
Table 1. Historical Overview of Opera and Technology [8]

Date Development

1581

Vincenzo Galilei publishes a book containing principles and acoustics of opera as discussed by Florentine Camerata

1619

Drawing upon Galilei, Johannes Kepler posits and publishes $3^{\text {rd }}$ law of orbital motion, which is evident in modern satellites

1637

1673

1726

1730

1823

1849

1849

1880

1881

1881

1882

1885

1888

1893

1894

1895

1896

1898

1900

1907

1913

1915

1919
Opera houses begin to use acoustic ducts

Athanasius Kircher proposes ducting music outside the opera house

Thomas Lediard uses moving-image projection at Hamburg opera

Collapsible telescope (monocular) in use in London

Voigtländer company sells binocular opera glasses

Antonio Meucci experiments with electronic sound transmission at the Gran Teatro Tacón opera house in Havana

Jules Dubosq projects an electric-light sunrise effect at the Paris Opéra

Edward P. Fry listens to opera via telephone

Clément Ader transmits stereo sound from Paris Opéra

British patent filed for gas-jet-illuminated libretto display in opera house

Albert Robida's Le Vingtième Siècle predicts (\& illustrates) opera delivered to homes via "téléphonoscope"

Based on 1884 telephone transmission, opera pay-cable service opens in Lisbon

Edison's motion-picture patent caveat declares it is for opera

Tivadar Puskás creates electronic newscast to increase utilization of operaby-phone lines

William Dickson plays music in first synchronized-sound movie

Opera via headphones (available in Lisbon since 1888) offered by Electrophone

First operetta films shown in Germany; Georges Hatot's Faust, released by Lumieres in 1897, based on Gounod's opera

La fille du regiment (Donizetti) is the $1^{\text {st }}$ filmed opera (two minutes) to be shown; Martha (Flotow) is shot on film

Martha is shown at the Eden Musée with live performers singing behind the screen; technique popular though 1922 cinema opera Jenseits des Stromes (Hummel) (with projected score at bottom of screen; other systems for cueing musicians in opera movies used small conductor image or signal lights built into the set)

Horace Short broadcasts opera from the top of the Eiffel Tower via a compressed air amplifier; Lionel Mapleson records from a non-interfering location (the wings of the Metropolitan Opera), creating some of the earliest live performance recordings

Ernani (Verdi) becomes the first "full-length" (abridged) recording of a complete opera, consisting in forty discs (eighty sides)

Radio transmission of opera singer leads to U.S. Navy use of radio as communication technique; "complete" Faust (22 arias) film using Chronophone; Caruso records "Vesti la giubba” (Pagliacci) a $3^{\text {rd }}$ time and it becomes the first million copy record (Platinum level according to RIAA)

First complete opera shot in U.S. with synchronized sound, Pagliacci (Leoncavallo)

Geraldine Farrar becomes silent-movie star based on success onstage as Carmen

Hugo Gernsback proposes live sound, distributed by radio, to cinemas projecting silent opera movies; Opera radio broadcasts in Chicago and New Brunswick, NJ via military transmitters, latter heard live 2000 miles out to sea 
Electronic recording and playback technologies emerge, standardizing techniques for both practices

1928 Washington Post reports opera singers on television

1931 Metropolitan Opera broadcasts via radio for the first time, Englebert Humperdinck's Hansel und Gretel

$1952 \quad$ Carmen (Bizet) transmitted live to cinemas in 27 cities

1976

First commercial digital recording is opera

1977 Metropolitan Opera broadcasts via television for the first time, Giuseppe Verdi's Rigoletto

1986 Opera Basel first plazacast of Gaetano Donizetti’s Lucia di Lammermoor

$1995 \quad$ Houston Grand Opera first plazacast

2006 Met HD plazacast to Times Square, international and HD cinema transmission

2009 Opera de Rennes broadcasts Wolfgang Amadeus Mozart’s Don Giovanni live to cinemas in 3-D

2009 International, digital, high-definition, satellite, multi-language-subtitled, surround-sound, live cinema versions of opera

Robert Eaglestone's foregoing characterization of technology applies presciently to writing, whether text, computer code, or music, reflecting the thoughts and creativity of an author. Thus, written music represents not only a composer's creativity (bringing into existence something which has not existed in the form designated by an author), but also the result of a technological practice that encodes ideas in a transmissible form. Musicologists have largely accepted that scores are not the sole representative of a musical work, recognizing that writing music conceals the actual musical entity. Cook (2013) echoes this view, characterizing the actions of performers (reading a score and acting upon it) and listeners (engaging the aural results of performers' actions) as a "slippage between two senses of 'expression'” along a communicative chain from composer to listener (p. 31). The communicative chain, which Cook identifies as a longstanding characteristic of music in scholarly discourse, is necessary because whatever the composer has conceived remains hidden from others until its inscription for preservation or sharing. Even Rudolph Kolisch's assertion that "the entire need for performance disappears if one can read music", perhaps unintentionally, admits that musical notation conceals the thoughts of the composer (Cook, 2013, p. 8). This concealment occurs because, as philosopher Jacques Derrida's stipulated, "Writing reduces the dimensions of presence in its sign" (Derrida, 1974, p. 281). A musical score, as a written entity, reduces the ways in which one can encounter the presence of the musical work by forcing the encounter into the visual realm, thereby restricting engagement by other senses. The score enables the sounds of a musical entity (what Heidegger characterizes as that which presences) to come into (aural) appearance repeatedly, but is not itself the musical entity. [9]

Jacques Derrida further expounds on this point, considering "the epoch of logocentrism" as "a moment of the global effacement of the signifier [the written word]" (Derrida, 1974, pp. 285-6). This effacement creates a mode of thinking in which "one then believes one is protecting and exalting speech [by adherence to the written text], [but] one is only fascinated by a figure of the techn $\overrightarrow{\boldsymbol{e}}$ "(Derrida, 1974, p. 286, emphasis added). Such fascination stems from Derrida's steadfast belief in Jean-Jacques Rousseau's assertion of two hundred years earlier: "Writing is nothing but the representation of speech; it is bizarre that one gives more care to the determining of the image than to the object" (Derrida, 1974, p. 27). In other words, written representations are not and cannot be the ideas that they represent. Similarly, speaking produces auditory phenomena representing the idea, rather than the idea itself, and is also a form of techne. Hermeneutic philosopher Hans Georg Gadamer reasserted a performance's status, arguing that the written component of an aesthetic entity lies in its ability to connect the past and present. [10]

Gadamer's stipulation about written works also applies to musical practice. It implies that there is no inherent codependency or inherent important differentiation possible between a written score and the sounded notes: "The fact that aesthetic being depends on being presented, then, does not imply some sort of deficiency, some lack of autonomous meaning. Rather, it [aesthetic being] belongs to its very essence. The spectator is an essential element in [what] we call aesthetic” (Gadamer, 2014, p. 130). Gadamer goes so far as to claim that it is in performance, and not in the written score, that one encounters the musical work: 
The performance of a play, like that of a ritual, cannot simply be detached from the play itself, as if it were something that is not part of its essential being, but is as subjective and fluid as the aesthetic experiences in which it is experienced. Rather, it is in the performance and only in it - as we see most clearly in the case of music - that we encounter the work itself. . .A drama only really exists when it is played, and ultimately, music must resound (Gadamer, 2014, p. 120).

This idea suggests that what is more important is the action of bringing a work into being, what I term "opsicentrism," rather than the text of a work itself, unlike "logocentrism," which preferences the written word as the primary embodiment of a musical work. [11] Sounded music, which implies the labor of producing the sound, rather than any other sensorial mode of it — written, imagined, physically felt - is thus the singular mode by which anyone can come closest to encountering the musical work itself. Nevertheless, strict adherence to Gadamer's constructs of opsicentrism and logocentrism produces an ultimately untenable binary, especially for texted music. Musical works consist then, at minimum, in their sounded phenomena, sung text (if present), and written score.

Of course, the challenge with music is its evanescent temporality-its sounded and intangible existence ceases almost as soon as it comes into being. The ephemerality of a performed music entity requires something to continue to allow its ongoing realization. Each realization (performance) of a musical work is the revealing that brings it forth: poiessis (Heidegger, 1977, p. 29). Gadamer (2014) asserts that “[A work's] own original essence is always to be something different (even when [performed] in exactly the same way). It has its being only in becoming and return" (p. 126). Clarke (2012) reminds his readers that "Novelty and uniqueness... are central to that powerful and Romantic notion of creativity which still dominates our culture" (p. 20). This reminder follows his description of pianists playing the same work, either in comparison with each other or against themselves individually. In other words, according to Nicholas Cook (2013), "Music's communicative potential—its ability to enact openness to the other—. . . is built into practically all musical performance and listening” (p. 412).

Musical works, which, by their nature intersect again and again with audiences only in their coming into being or presencing (Anwesen) via the performers bringing-forth (Her-vor-bringen), are convincing testaments to humans' inability for exact mechanical reproduction (Heidegger, 1977, pp. 10-1). [12] Gadamer (2014) expands on music's Her-vor-bringen as evidenced in its occasionality: "The work of art. . .experiences a continued determination of its meaning from the 'occasion' of its coming-to-presentation. This is seen most clearly in the performing arts, especially theater and music, which wait for the occasion in order to exist and define themselves. ..” (p. 147). Acknowledging the viability of opsicentrism becomes an integral step in coming closer to encountering the musical work.

Rather than blindly accepting either logocentrism or opsicentrism and abandoning the other, however, I suggest a reinvestment in Heideggerian ideals for musical performance. Neither the score nor the performance contains the entire Wesen of the musical entity; thus, neither one constitutes that entity completely. Instead, both point to it, and the aesthetic being that is music is perhaps like a performance of music itself: intangible. Because the score endures, and is therefore (only) one embodiment of the Heideggerian Gestell of music, the score is the essencing of technology, the techne of the musical work. Gadamer's conception of every performance's uniqueness in relationship to the nature of a work reveals a prescient awareness of any performance history's inherent dynamism. For him, what is "essential to dramatic or musical works, then, is that their performance at different times and on different occasions is, and must be, different. . .specifically occasional art forms determine [themselves] anew from occasion to occasion" (Gadamer, 2014, pp. 147-8). Both a musical score and its realization belong to techne because they each point to the revealing of the musical work, which is poietic. Those who endeavor in either practice-i.e. in the pursuit of revealing by composition or performance-both exhibit and affirm how tangible practices link to intangible concepts. Heidegger (1977) reminds his audience that:

Here was a time when it was not technology alone that bore the name technēe. Once that revealing that brings forth truth into the splendor of radiant appearing also was called techne. Once there was a time when the bringing-forth of the true into the beautiful was called techne. And the poiessis of the fine arts was also called techne (p. 34). 


\section{NEW MUSICAL OBJECTS FOR DISCOURSE}

As numerous scholars have noted, digitally-based technologies and methodologies significantly enhance the range of investigations and outputs in performance analysis. [13] The Centre for the History and Analysis of Recorded Music's (CHARM's) "Mazurka Project” affirmed tempo as a logical first step in the analysis of musical performance. [14] Tempo is especially fitting for operatic analysis as pacing is central to understanding an opera's performed dramatic arc. Puccini's works are particularly subject to pacing, as Luigi Ricci - accompanist and vocal coach who worked with Puccini in the 1910s - recalled in stipulating ten essential rules of performing a Puccini opera that he learned from the composer. The first rule regards tempo and its effects upon pacing, and comprises nearly three full pages, while the other nine rules together fill just over three pages, highlighting Puccini's obsession with musical and dramatic timing. [15] Future analysis of other physical properties of sounded music - dynamics, pitch, timbre, articulation, phrasing, and dictionwill only enhance understanding of what a performance was or is.

\section{Methodological Considerations}

The present analysis further adapts the hierarchical Time Scape technique of tempo tracking, developed by CHARM, as the tool for operatic analysis. By incorporating textual underlays with Time Scapes, this method facilitates understanding of temporal-textual emphasis and aspects/elements of performers' creative processes. How singers deliver the text in the context of the musical structure provides valuable insight into the kind of character they portray. While Daniel Leech-Wilkinson (2007) has also analyzed singers' expressivity in relation to sung text of Schubert's lied "Die jenge Nonne”, his approach focused on individual moments or phrases and durations of the entire song without extended consideration of connections between them. Scape plotting is useful for capturing both surface-level details and the overall hierarchical structure simultaneously while also enabling examination of the connections that Leech-Wilkinson's foundational work did not cover.

To create the scape plots, beat tapping and tempo calculation (to the following beat) using Sonic Visualiser provided the basic data for use in this study. For Giordani's performance, the process was to extract the digital audio from the commercially available DVD, then enter and adjust beat markers with onset detection. For Gruber's performance, which is not commercially available, data generation followed a process I designed to accommodate legal restrictions on archival material: 1) annotation of a score while listening, 2) tapping beats on a second listening, 3) comparing tap track and recording on a third listening while making further annotations for subsequent listening, 4) listening and tapping with new information, 5) repeating steps 3-4 until creation of a tap track reflecting beat placement, and 6) upload file into Sonic Visualiser for placement, onset detection, and tempo calculation (Neumann, 2016b, p. 50). I then used his tempo data in CHARM's web-based Scape Plot Generator tool to create the Time Scapes in this study (http://www.mazurka.org.uk/software/online/scape/).

Since Time Scapes form the basis of the following analysis, an overview of reading them with the overlay in use here is necessary. Four elements nuance the understanding of these Time Scapes. First, color coding reflects basic relationships to the overall average, or global, tempo of a performance; yellow, orange, and red are progressively faster than average (green), while blue indigo and violet are progressively slower. Second, a structural overlay indicates approximate divisions of surface (beat-to-beat tempo relationships), mid-ground (phrasal connections) and background (global tempo). Third, a tempo contour graph and linear trend line respectively indicate precise tempo values of the surface level and reflect the overall pacing tendencies within the performance, while the final and perhaps most critical element, the textual underlay, reveals a performance's unique temporal-textual emphases.

Structural analysis of the tempo hierarchy in relationship to the text is necessary for understanding the temporal-textual emphases hierarchy and its possible ramifications for dramatic interpretation. Examination of the surface level — the bottom third of each Time Scape-reveals how singers' deviations from the global tempo have the effect of accentuating or understating different elements of the text. A performance's temporal-textual emphases can align with a score's indications or result from performer decisions alone. On their own, each surface-level emphasis highlights individual words or phrases. For example, if one spends more time delivering the word "amore" than the word "colore," then the word "amore" receives a greater temporal-textual emphasis, suggesting the speaker's designation that it is the more important word. Surface level deviations from the global tempo have the same effect, whether the cause of 
the performed effect is based in notation or in aural phenomena. On their own, each of these surface-level emphases highlights individual words, but when their emphasis crosses another one in a higher (or deeper) structural level, a structural crossing links the two words.

The middle third of each Time Scape reflects the structural mid-ground of a performance, and in this space temporally-based connections between non-neighboring parts of the text can emerge. Such links are evident when extensions of homogenous color from surface level events intersect in a deeper structural level. Not only do these structural crossings further substantiate each performance's uniqueness, but, moreover, their respective hierarchical levels reflect a hierarchy of textual connections. For example, the emphases added in the following line changes what it communicates as most important to a reader; "The blue cow jumped over the purple moon" stresses the unorthodox coloring of the sentence's modified subject and object on the surface, but in a deeper level, it connects these two components, so perhaps the sentence is about imaginative color schemes. Alternatively, "The blue cow jumped over the purple moon" stresses the cow jumping, already a rare occurrence, but by connecting this temporal emphasis to the moon's color, perhaps the reason for the cow's odd behavior is that purple evokes such a strong reaction.

Understandably, this hierarchical structure depends largely on the imposed ordering of text and music by composers and librettists-here Puccini, Giuseppe Adami and Renato Simoni. As previous research has established (at CHARM and elsewhere), however, performer decisions contribute greatly to variations in hierarchical tempo structures. While it may be possible to discern such connections in listening alone, they generally become more difficult to discern as one moves higher in the structure, and the longer the passage of music to which one listens. The top third of each Time Scape is predominantly green, unless there are connections between parts of the text at the beginning and end of an excerpt, or a moment-specific tempo modification strong enough to occupy an organizational space in the hierarchy. As these extensions cross at higher levels of a performance's tempo hierarchy, their importance in the overall structure for what they link increases.

Most tempo modulations in the present study are ritardandos, resulting from notated and non-notated fermatas, tenutos, and other note-specific articulation marks. Combined with Puccini's well-documented obsession with tempo and pacing, these distinct modulations in relationship to text delivery form the rationale for hierarchical analysis of textual connections based on temporal emphasis. This performance and performer centric view is not to give preference to these aspects over a score, libretto, staging, etc., but only to focus on their part of the aforementioned dialogic relationship in the continual creation of operatic works. In the following graphs - the central components of the analysis here undertaken - the temporal-textual emphases result largely from the varying applications of tempo rubato, and also from Puccini's notated metric and beat structure.

Each case study presented here followed the same analytical protocol: 1) analysis of temporaltextual emphases with the preceding method, which enabled the 2) formation of a hypothesis about its performer's interpretation, 3) interview with each singer to apprehend their unique understanding of and motivations for their characters in the musical moments this project analyzed, 4) share hypothesis/conclusion drawn from Time Scape and temporal-textual emphasis analyses, and 5) confirm veracity of empirical findings against performer characterization. In each case, my hypothesis matched how Gruber and Giordani described their respective interpretations. [16] Confirming such hypotheses via interview, as in the present study, or other secondary sources makes this approach useful for interrogating performers' creative processes both within a performance and across performances in the context of the performance history of an operatic work.

\section{CASE STUDIES}

The remainder of this article demonstrates a manner of profiling the tempi encoded in available recorded broadcasts of Turandot at the Metropolitan Opera for Andréa Gruber's 29 January 2005 performance of 'In questa Reggia' and Marcello Giordani's 7 November 2009 iterations of 'Non piangere, Liù' and 'Nessun dorma.' These recordings are particularly useful for the approach detailed in this article, given Giordani's and Gruber's granting of interviews. While recorded performances of these singers' interpretations are the focus of this study, they represent two (relatively late) points in a fifty-season performing history for Turandot at the Met, from which nineteen recordings are currently accessible. 


\section{Andréa Gruber: Turandot as Charade, 29 January 2005}

Turandot's entrance aria, 'In questa Reggia' and the ensuing riddle scene form the crux of both her character and the opera's dramatic arc. In this aria, Turandot explains her riddles and the ostensibly severe consequence of failing to answer them - her desire for vengeance on behalf of her ancestress Lou-o-Ling, as Table 2 illustrates. [17] Taken at her word, Turandot is bloodthirsty, vengeful, and cruel. According to Andréa Gruber (2015), both Birgit Nilsson's icy, steely timbre and dominance of the role on the stage throughout the 1960s solidified these traits as Turandot's true nature in the imagination of audiences. [18]

The Time Scape in Figure 1 represents Andréa Gruber's performance as Turandot on 29 January 2005. Here, tempo modifications reflect the musical structure of the aria: twenty bars of 2/4 marked molto lento with 46 quarter notes per minute and covering beats 1-41, sixty-eight bars of 4/8 interspersed with three bars of 2/8, with indications of lento and 66 eighth notes per minute for beats 41-111, and finally twenty-two bars of 4/4 marked largamente with 56 quarter notes per minute over beats 113-199. In this analysis, the 2/8 and $4 / 8$ measures were analyzed based on quarter note equivalency in order to accommodate limitations of accounting for meter shifts in audio files in Sonic Visualiser.

Much of the tempo hierarchy in Gruber's performance is similar to the other eighteen performances of this aria at the Metropolitan Opera between 1960 and 2009. [19] Unlike for Birgit Nilsson in 1961 (top left in Figure 1) or Maria Guleghina in 2009 (middle left in Figure 1), the higher-level structure of Gruber's large-scale slower-than-global-tempo section (b. 41-113) does not extend to the left edge of the graph in a significant manner. This feature is the result of Gruber's comparatively quicker tempi through the aria's introductory text (b. 1-41) in relationship to her performance's global tempo, as the lack of surface-level green in this section indicates. The leftward extensions touching the edge of Nilsson's and Guleghina's Time Scapes result from beats 111-113 — where their onstage Turandots each emphasize Lo-u-Ling's scream and death. These emphases project a greater importance in communicating Lo-u-Ling's victimhood, perhaps suggesting a motivation substantially predicated upon vengeance. The absence of this extension for Gruber's performance insinuates that retribution is not an all-consuming impetus for her Turandot's riddles (which take place in the ensuing scene). Analysis of all recorded performances of 'In questa Reggia' at the Met reveals that the extension in question is also present at the left edge of the time scapes for Birgit Nilsson's performances in 1962, 1966, 1970, as well as for Marion Lippert (1969), Ingrid Bjoner (1974), Elinor Ross (1974), Eva Marton (March and April 1987), Ghena Dimitrova (1988, 1996), Gwyneth Jones (1990, 1992, 1995), and Adrienne Duggar (2003). This subtle difference in structural features unique to Gruber's performances results in a dramatically distinct narrative alteration from other Turandots at the Met. 
Table 2. Text and Translation of 'In questa Reggia'

\author{
Turandot \\ In questa reggia, or son mill'anni e mille, \\ un grido disperato risonò. \\ E quel grido, traverso stirpe e \\ stirpe \\ qui nell'anima mia si rifugiò! \\ Principessa Lou-Ling, \\ ava dolce e serena che regnavi \\ nel tuo cupo silenzio in gioia pura, \\ e sfidasti inflessibile e sicura \\ l'aspro dominio, oggi rivivi in me!
}

\section{La Folla (sommessamente)}

Fu quando il Re dei Tartari

le sette sue bandiere dispiegò.

\section{Turandot (come cosa lontana)}

Pure nel tempo che ciascun ricorda,

fu sgomento e terrore e rombo

d'armi.

Il regno vinto! Il regno vinto!

E Lou-Ling, la mia ava, trascinata

da un uomo come te, come te straniero, là nella notte atroce

dove si spense la sua fresca voce!

\section{La Folla (momora reverente:)}

Da secoli ella dorme

nella sua tomba enorme!

\section{Turandot}

O Principi, che a lunghe carovane

d'ogni parte del mondo

qui venite a gettar la vostra sorte,

io vendico su voi, su voi quella purezza,

quel grido e quella morte!

Quel grido e quella morte!

Mai Nessun m’avra! Mai nessun,

nessun m'avrà!

L'orror di chi l'uccise

vivi nel cuor mi sta.

No, no! Mai nessun m’avrà!

Ah, rinasce in me l'orgoglio

di tanta purità!

(e minacciosa, al Principe:)

Straniero! Non tentar la fortuna!

'Gli enigmi sono tre, la morte una!'

\section{Il Principe Ignoto}

No, no! Gli enigmi sono tre, una è la vita!

\section{Turandot}

No, no!

[Gli enigmi sono tre, la morte è una!

Il Principe Ignoto

Gli enigmi sono tre, una è la vita!]

\section{Turandot}

In this palace, a thousand, thousand years ago,

A desperate cry resounded.

And that cry, through descendant and descendant,

Took refuge in my soul!

Princess Lou-Ling,

Sweet and serene ancestress, who reigned

In your dark silence, in pure joy,

And who defied, inflexible and sure,

Bitter domination, you relive in me today!

The Crowd (quietly)

It was when the king of the Tartars

Unfurled his seven flags!

\section{Turandot (like something remote)}

Still, in the time that everyone remembers,

There was alarm, and terror in the rumble of arms!

The kingdom defeated! The kingdom defeated! And Lou-o-Ling, my ancestress, dragged away By a man like you, stranger, like you, foreigner, There in the atrocious night,

Where her fresh voice was extinguished!

\section{The Crowd (murmurs reverently:)}

For centuries she has slept

In her enormous tomb!

\section{Turandot}

O Princes who in long caravans

From every part of the world

Come here to try your fate,

I avenge upon you, upon you that purity,

That cry and that death!

That cry and that death!

No one will ever possess me! No one ever,

No one will possess me!

The horror of him who killed her

Is alive in my heart!

No, no! No one will ever possess me!

Ah, in me is reborn the pride

Of such purity!

(and, threateningly to the Prince:)

Never anyone, anyone shall have me!

'The riddles are three, the death is one!'

\section{The Unknown Prince}

No, no! The riddles are three, one the life!

\section{Turandot}

No, no!

[The riddles are three, the death is one!

The Unknown Prince

The riddles are three, one the life!] 


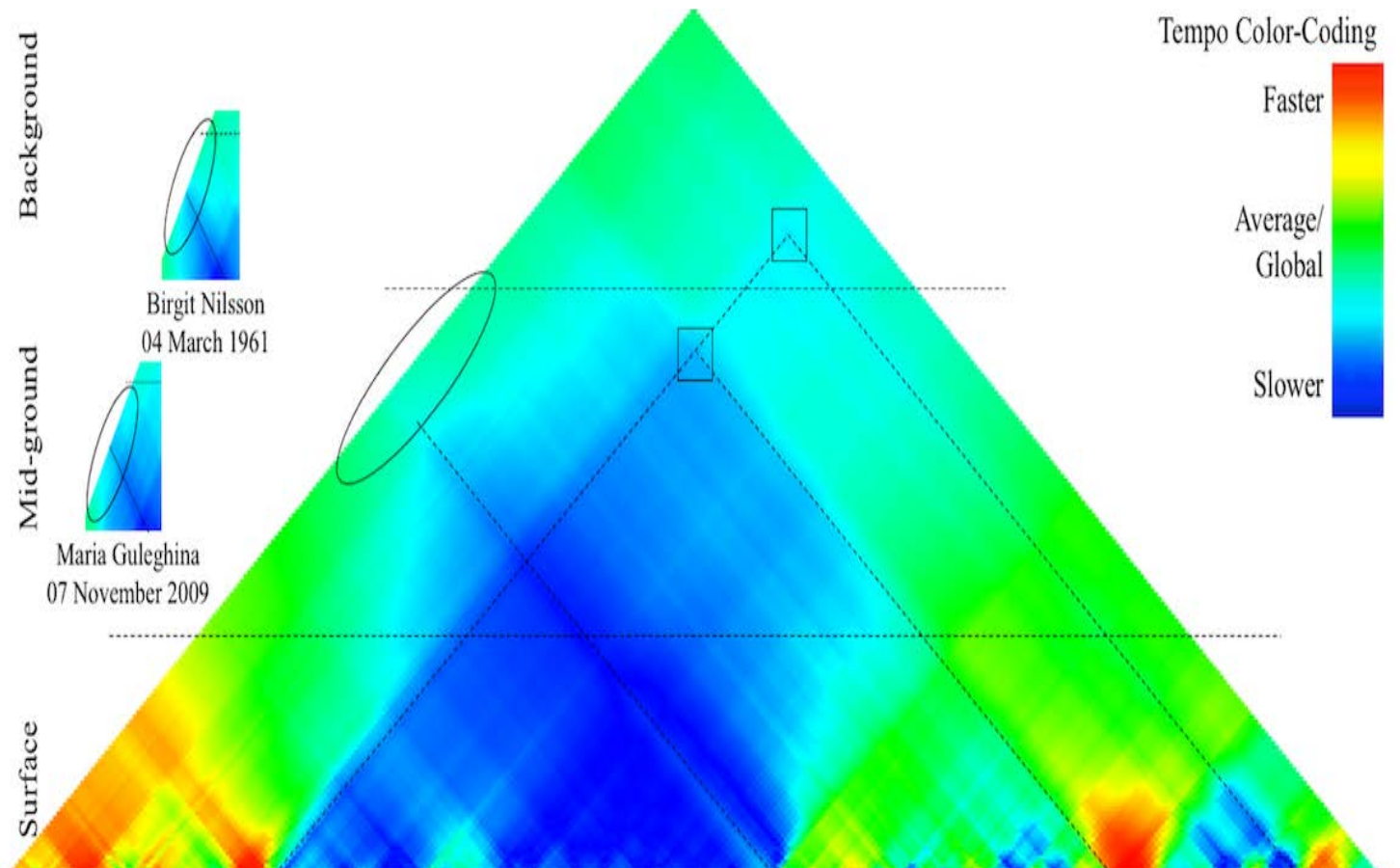

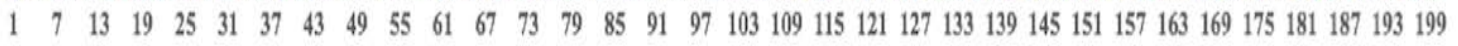

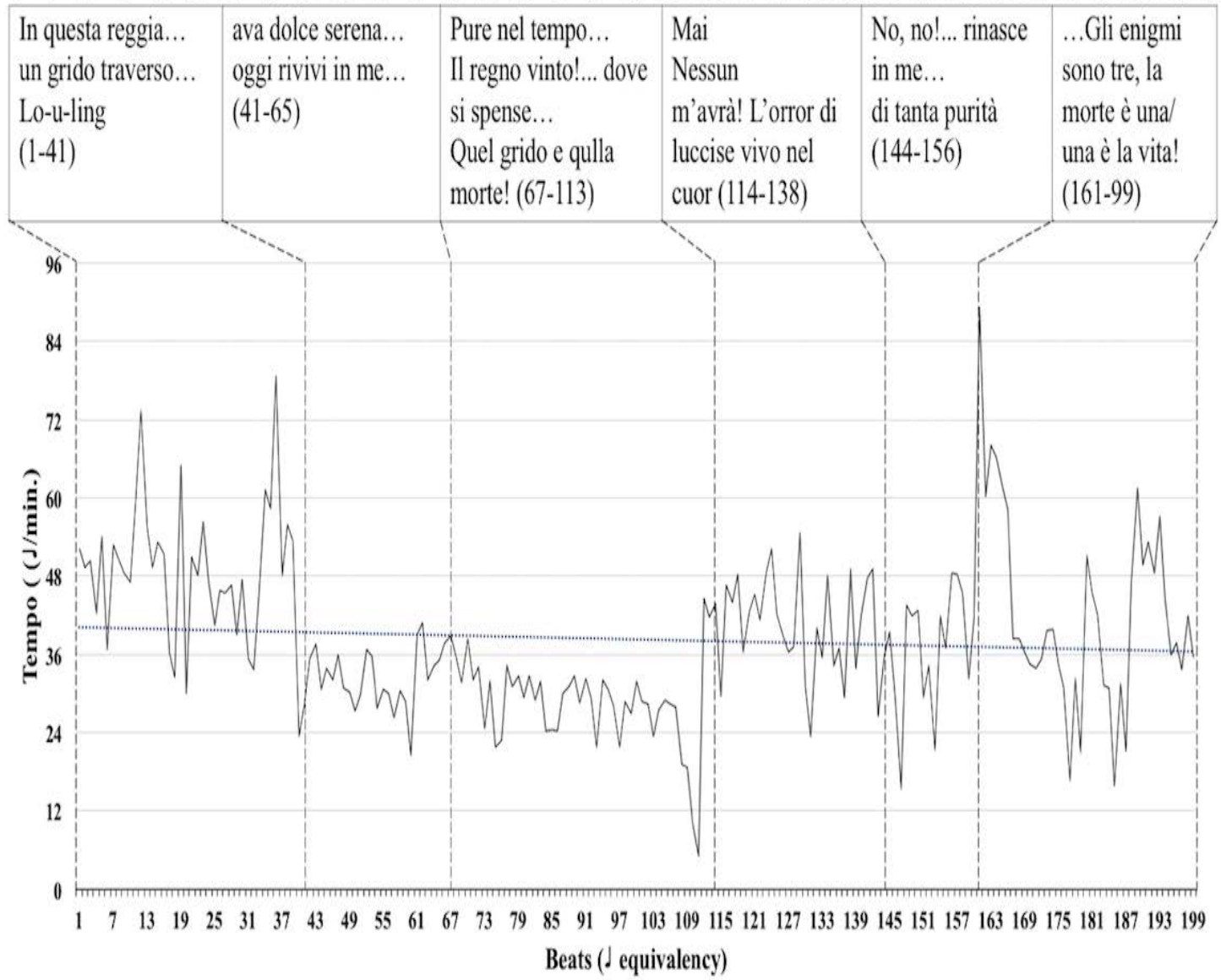

Figure 1. Time Scape, text, and tempo contour graph (with linear trend line) for Andréa Gruber 29 January 2005 'In questa Reggia’ 
The most striking higher-level features in this performance's tempo hierarchy are the structural crossings resulting from the extension of Turandot naming Lo-u-Ling intersecting two others, both involving Calaf. The first crossing for the "Lo-u-Ling" extension emanates from the prince's first interjection in this aria, 'No! No! Gli enigmi sono tre, una è la vita!' (b. 173-180). The second extension originates at Calaf's and Turandot's dual ascent wherein they challenge each other (b. 181-188). These are the highest significant structural crossings in this tempo hierarchy, and the tempo-textual emphasis they highlight points to the crux of Gruber's interpretation of this role. "She thinks she is Lo-u-Ling, but this is an effect of her being only thirteen, just becoming sexually aware, and really pissed off at her father for trying to control her and marry her off. I think he is the one who makes her do the riddles. So, the anger is there, but it's not some sense of real and righteous anger over Lo-u-Ling” (Gruber, 2015).

The libretto indicates that Turandot seeks revenge on all men for the travesty inflicted on Lo-u-Ling, but the surface meaning of the text does not reflect the complexity necessary for Gruber's preferred characterization. In her view, Turandot is a coming-of-age thirteen-year-old who is a pawn in her father's game of suitors, riddles, and beheadings. Believing Lo-u-Ling is reborn in her or that she is Lo-u-Ling provides a two-fold escape for Turandot—one from her father's domination of her will and actions (which explains part of Turandot's identifying with her ancestress), and the other from her burgeoning sexuality, which she has no way to control. Also for Gruber, Turandot knows from the moment she sees Calaf that he is different from all previous suitors, who Gruber imagines as motivated by the allure of the power coming from a royal marriage and the prospect of satiating their respective sexual appetites. Gruber (2015) highlights this recognition about Calaf as the precipitating factor in Turandot's Act III tearful confession, wherein the character exclaims: "My first tears, yes stranger. When you arrived, I felt with anguish the fateful thrill of destiny, but I trembled for you! There was in your eyes the light of heroes!”. [20]

Under these circumstances, the links extending from Calaf's outbursts indicate his awareness of Turandot's situation and his confidence that he will free her from her present bondage. Singers who approach Calaf in this way are the most dramatically convincing for Gruber (2015), while those following a more stereotypical solely selfishly motivated archetype for Calaf present interesting challenges in onstage chemistry: "Calaf as only a sexual conqueror limits how Turandot (and I as Turandot) can interact with him from this aria onward in the opera. The riddles can be so many things: seductive, angry, cat and mouse, among others” (Gruber, 2015). Because Gruber looks to Act III's tearful admission as the fundamental dynamic between Calaf and Turandot, she cannot conceive of "In questa Reggia" as an angst-ridden cry for help to Calaf, whose very "ascent to the gong at the end of Act I and ascent to answer the riddles in Act II leaves [Turandot] shaking” (Gruber, 2015). In the aria’s climactic parallel octaves with simultaneous and contradictory texts about three riddles equaling one death or one life, Calaf senses Turandot's trepidation (which she masks with her death threats) about a life different from the one she knows. Gruber (2015) summarizes this moment: "Calaf knows he can break the spell of Turandot's release-by-obsession by outsmarting her father and arousing her erotic love." Such a detail emerging in the tempo hierarchy and temporal-textual emphasis of Gruber's performance demonstrates, as it does also with Marcello Giordani's performances, both a spectrum of nuances in musical and dramatic practice that range from minute to profound, and the applicability of this methodology to better understanding the creative process. Being able to connect singers' dramatic interpretations to their onstage musical behaviors in this manner represents perhaps the most significant contribution to this vein of inquiry.

\section{Marcello Giordani: Breaking Stereotypes of Calaf, 7 November 2009}

\section{'NON PIANGERE, LIÙ!’}

'Non piangere, Liù!' is Calaf's response to Liù's expressed concern ('Signore, ascolta!') over his stated intent to answer Turandot's riddles. The aria's text bears a wide array of dramatic interpretations. On one hand, it can be a tender response to Liù's worry; alternatively, it seeks only to provide continued care for Timur (Calaf's father) in the event of Calaf's death, thereby using Liù to assure such an outcome. The social classes of Calaf (the exiled Prince of Tartary) and Liù (a slave in the royal household), the gender roles and social places of men and women as Puccini was writing Turandot, and Puccini's problematic relationships with women provide a strong, yet unsavory to modern tastes, archetype. Herein, the prince's order of concerns might be: 1) add Turandot to his list of conquests, 2) ensure ongoing caregiving for Timur, and maybe 3) console Liù in her moment of distress. Other interpretations of the plot development likely include some mixture of the foregoing priorities; like with Gruber's uniqueness in "In questa Reggia," most performances 
at the Metropolitan Opera for 1961 - 2009 exhibit less focus on Liù via temporal-textual emphasis, with Marcello Giordani a notable exception. [21]

Figure 2 offers a view of the temporal hierarchy and temporal-textual emphases in Giordani's interpretation on 07 November 2009. On the surface, Giordani delivers the opening words and 'dolce mia fanciulla' (emphasis added) slower than the global tempo (beats 4-9, 19-21, respectively). He provides Calaf's explanation that Timur may be alone in the world at dawn at a mildly-to-moderately quicker than average tempo before slowing significantly to exhort Liù to 'portalo via con te' (beats 41-4). Giordani's Calaf urges Liù to focus, following her interjection, with a significant slowing at 'questo, questo' (beats 61-5). The greatest temporal emphasis in Giordani's performance builds on this moment, as Calaf re-addresses and recharacterizes the slave girl as 'mia povera Liù' with the 'piccolo cuore,' which is perhaps unsurprising, as Puccini's markings include an espressivo (beats 66-72). Giordani's subsequent stringendo reminds Liù that her heart does not falter and asks her to plead for Timur (beats 72-84). Following this surge towards the melodic climax, Giordani’s Calaf places Liù's attention on Timur, and emphasizes the need to do so through his observation of the fermata Puccini placed at the repetition of 'che non sorride più' (beat 85).

Table 3. Text and Translation of 'Non piangere, Liù!'

$\begin{array}{ll}\begin{array}{l}\text { Il Principe Ignoto (avvicinandosele, con commozione) } \\ \text { Non piangere, Liù! }\end{array} & \begin{array}{l}\text { The Unknown Prince (approaching her, with } \\ \text { emotion) }\end{array} \\ \text { se in un lontano giorno } & \text { Don’t cry, Liù! } \\ \text { io t'ho sorriso } & \text { If on one far-off day } \\ \text { per quel sorriso, dolce mia fanciulla } & \text { I smiled at you, } \\ \text { m'ascolta: il tuo Signore } & \text { For that smile, my sweet girl, } \\ \text { sarà, domani, forse, solo al mondo } & \text { Listen to me: your Lord } \\ \text { Non lo lasciare, portalo via con te! } & \text { will be, tomorrow, perhaps alone in the world. . . } \\ & \text { Do not leave him, take him away with you! }\end{array}$

Liù

Noi morrem sulla strada dell'esilio!

\section{Timur}

Noi morrem!

\section{Il Principe Ignoto}

Dell'esilio addolcisci a lui le strade Questo...questo, o mia povera Liù, al tuo piccolo cuore che non cade chiede colui che non sorride più. . . Che non sorride più!

\section{Liù}

We'll die on the road of exile!

\section{Timur}

We'll die!

\section{The Unknown Prince}

Make gentle the roads of exile for him This. . .this. . .Oh, my poor Liù, Of your little heart that doesn't fail

He asks who smiles no more. . . Who smiles no more! 


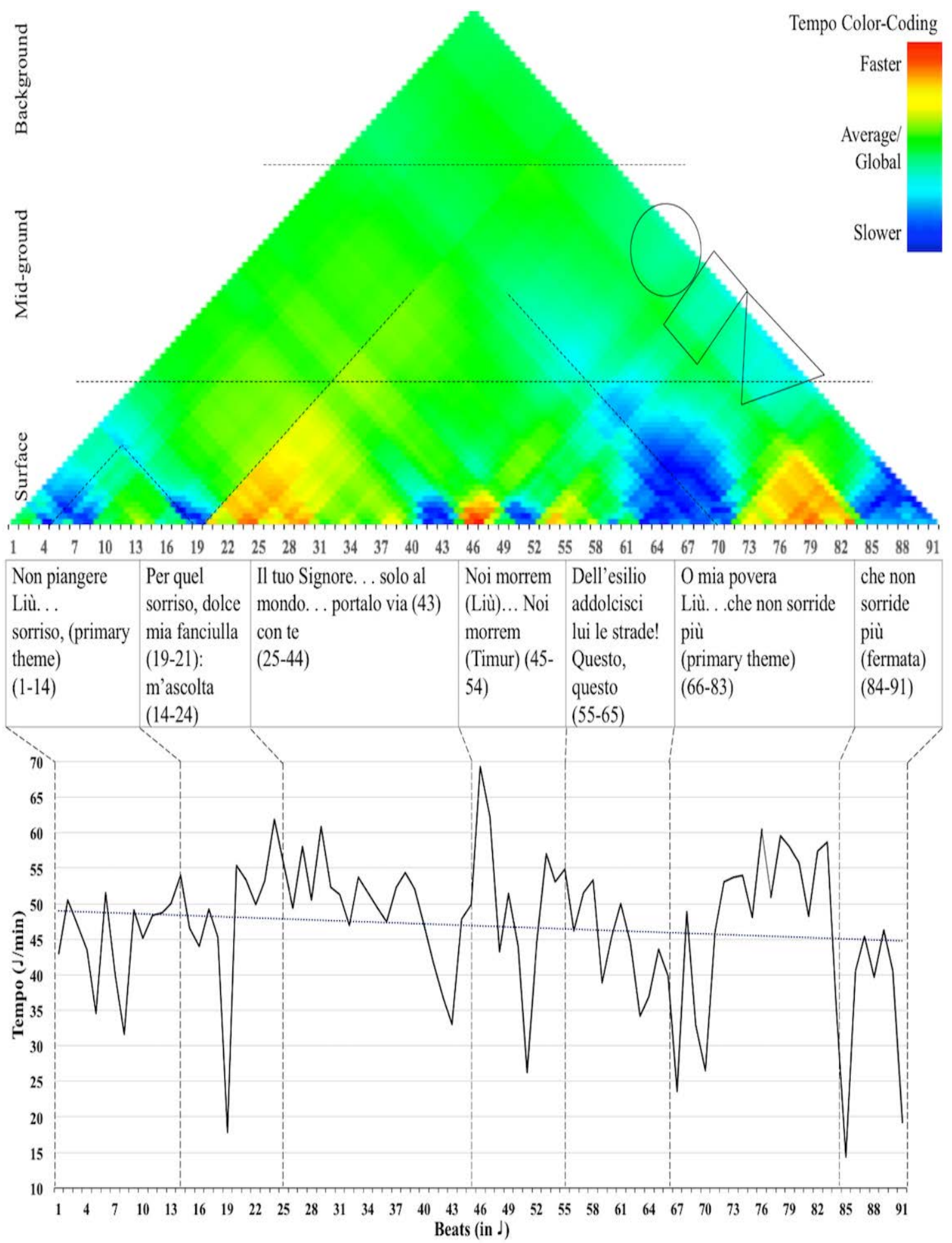

Figure 2. Time Scape, text, and tempo contour graph (with linear trend line) for Marcello Giordani 07 November 2009 'Non piangere, Liù!’

Several features of the tempo hierarchy in this performance are noteworthy. First, and most striking, are the heights to which extensions from the most significant stringendo and ritardando extend. More interestingly, they do not actually cross, offering only a projected or implied intersection almost in the middle of the triangle, as the lines in Figure 2 indicate. That they do not cross establishes the temporally and structurally significant independence of two specific points as the primary components of this performance's identity. The first results from Giordani's pushing the tempo through his initial explanation to Liù (which is 
his concern for Timur) and the second from his slowing at Calaf's re-focusing on Liù's identity. If either extension was absent, then the remaining temporal feature would dominate the hierarchy of Giordani's performance, along with its text. Moreover, Giordani's temporal link of 'Non piangere, Liù' (beats 4-6) and 'dolce mia fanciulla' (beats 19-21) highlights both his characterization of Liù and Calaf's concern for her and Timur. [22] Citing his perception of Calaf's understanding of the need to care for father and slave, Giordani indicated that his interpretation in this moment generally tends to be Calaf's focus on everyone as individuals, "like God," and that this universal concern offers at least a shadow of connection amongst the characters [23]: "He looks out for everyone, because Turandot's cruelty upsets him, because he knows suffering and exile" (Giordani, 2013).

Furthermore, the blue and indigo shading along the right edge of the graph are increasingly higher structural projections from 'O mia povera Liù' (triangle, emanating from beats 66-71), Liù's 'sulla strada dell'esilio' (rectangle, emanating from beats 50-52), and 'portalo via con te' (square, emanating from beats 40-43), respectively. These extensions all cross with the subtle upward projection from the fermata emphasizing Timur's inability to smile anymore (beat 85). That the highest structural significance comes from the crossing with 'portalo via con te' suggests that one possible underlying or subconscious focus in Giordani's performance was a greater concern for Timur than for Liù, which would correspond to his royal station in society. At the very least, in concluding Act I on this occasion, Giordani's Calaf showed concern for the well-being of everyone surrounding him in ancient Peking, and, convinced by a glimpse of Turandot in her legendary beauty, that the means to creating a healthier society is to help the Princess understand that she can give in to love and preserve her identity.

\section{'NESSUN DORMA'}

'Nessun dorma!' is perhaps Puccini's best-known tenor aria, owing both to its iconic musical features, and to its crossover success. Its text is ostensibly one of the more selfish expressions in Turandot, if not the entirety of Puccini's output. One way to read it is that Calaf cares nothing for anything but himself, daring not just Turandot, but the very setting in which, and objects (stars) to which, he offers his soliloquy. Such a reading is not out of place considering the cultural sphere from which this work emerged - one in which women had limited agency. Giordani's version however, is a unique re-imagining of a Puccinian tenor archetype.

Table 4. Text and Translation of 'Nessun dorma!'

\section{Il Principe Ignoto}

Nessun dorma! Nessun dorma. . .!

Tu pure, o Principessa, nella tua fredda stanza, guardi le stelle

che tremano d'amore e di speranza!

Ma il mio mistero è chiuso in me, il nome mio nessun saprà!

No, no, sulla tua bocca lo dirò

quando la luce splenderà!

Ed il mio bacio scioglierà il silenzio

che ti fa mia. ...!

Voci di Donne (misteriose e lontane)

Il nome suo nessun saprà!...

e noi dovrem, ahime, morir!

\section{Il Principe Ignoto}

Dilegua, o notte. . .! Tramontate, stelle!

Tramontate, stelle!

All'alba vincerò! Vincerò! Vincerò!

\section{The Unknown Prince}

Let no one sleep! Let no one sleep!

You too, O Princess,

In your cold room,

are looking at the stars

That tremble with love and with hope!

But my mystery is locked in me,

No one will know my name!

No, no, upon your mouth I'll say it

when the light shines.

And my kiss will break the silence

that makes you mine. ..!

Women's Voices (mysterious and remote)

No one shall know his name!

And we must, alas, die!

\section{The Unknown Prince}

Dissolve, o night. . .! Set, stars!

Set, stars!

At dawn I'll win! I'll win! I'll win!

By the time Act III arrives, Giordani’s Calaf has patiently listened to Turandot's defense of her hatred of man, successfully answered each of her three riddles, asserted that he does not want her against her 
will, but instead aflame with love, and even offered an 'out' to Turandot: discover his name by dawn and he will surrender his life. Unlike stereotypes for fin de siècle tenors as being only sexually supercharged on their most innocuous days or otherwise being outright sexual predators, Giordani's Calaf appears to be a genuinely decent human being by modern standards. Analysis of the temporal-textual emphases in his performance of "Nessun dorma!" supports such a characterization.

Figure 3 is the Time Scape for Marcello Giordani's performance of 'Nessun dorma!'. In it, various nested links of text are clear. First, the extension from the slowing throughout the initial address to the Princess (the line emanating from beat 18), which is very similar to Franco Corelli's 1961 version under Leopold Stokowski's baton, forms a link with the extension resulting from the slowing at the first syllable of 'splenderà!' (the line emanating up and left from beat 62). [24] This latter extension also forms an implied link with the stringendo Giordani and Nelsons employed between the first and second phrase of Turandot's most famous motive (beats 43-48), which temporally de-emphasizes Calaf's secret, and by extension, his power over Turandot and interest in making her a conquest. There is also a link between the ritardando on 'splenderà!' (line emanating up and right from beat 62), the ritardandos of Calaf's proclamation that Turandot's silence will make her his ('che ti fa mia!' beat 78-82), and the chorus's interjection about their anticipated collective fate (beat 83 - 96), highlighted by the larger oval in Figure 3. Extensions from each of these moments form links of varying intensities with the first and third of the threefold climactic iterations of "Vincerò!” (squares at beats 106-9 and 120).

The highest structural crossings between Calaf's opening lines and 'vincerò!' are common among performances of 'Nessun dorma!' at the Metropolitan Opera, implying that the overarching textual and dramatic point of this aria is to show, at the very least, Calaf's confidence, however individual performers choose to nuance it. Giordani's inclusion of the crowd's voice in the temporal hierarchy, however, is unique to his performance, and reinforces the conclusions drawn about his Calaf in the foregoing analysis of 'Non piangere, Liù." Had Giordani's temporal-textual emphases not drawn the crowd into the performance's hierarchy, his character's view of the situation would appear less sympathetic to them, and suggest a more insistent and ardently-focused motivation.

The distinct nesting of temporal-textual emphases in Giordani's performance suggests that these moments, if considered in increasing hierarchical order, share a commonality of effect. [25] The commonality of their effect-that Calaf will win Turandot's heart and hand in marriage-suggests the possibility of a commonality of motivation. In other words, Giordani's performance evokes a structure in which Calaf addresses everyone's concerns through his love for all, thereby embodying Giordani's interpretation of Calaf's state of being at the aria's point in the opera's dramatic arc. For him, "He loves everyone, because at this point, he is love" (2013). [26] Love in its truest, self-sacrificial sense is the motivation Giordani attempts to project in his performances as Calaf. This is also what makes Liù's death more moving for him as a singer, both as an actor preparing to portray a character, and then acting as that character. In Giordani's view, this also makes Liù's death a genuine turning point for Turandot, as the princess sees someone die for no personal benefit (2013). Giordani's frequent characterizations of his view of Calaf's embodiment of love as "like God's," challenges longstanding assertions the tenor at this point is a sexually motivated, autobiographical projection of Puccini's younger self. [27] 


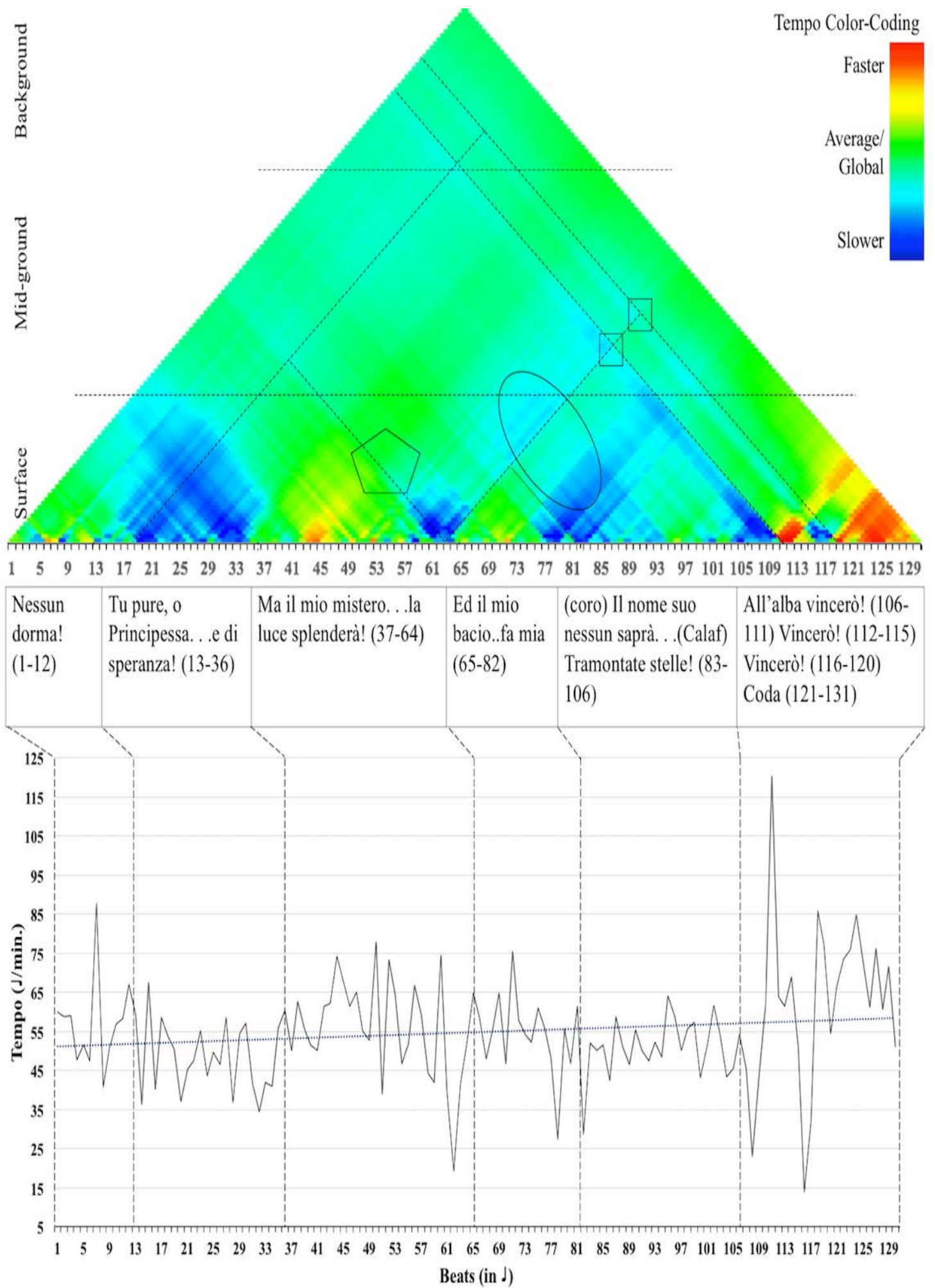

Figure 3. Time Scape, text, and tempo contour graph (with linear trend line) for Marcello Giordani 07 November 2009 'Nessun dorma!' 


\section{CONCLUSIONS}

\section{Creative Process Analysis}

Beyond affirming opera's interdisciplinary nature, each of the foregoing examples documents the identity of selected performances in terms of tempo-based phenomena - modulation, hierarchy, and temporal-textual emphasis. Such a means of capturing performance is useful in that it allows one to simultaneously glimpse both surface and hierarchical relationships of musical phenomena. By visually reflecting on-stage behaviors and their organization in time, Scape Plots can move analysis beyond the limits of language and score. These tools emphasize the importance of the point that opened the foregoing discussion: music is not merely its score; rather, its repeated instantiations through performance reveal its dynamic nature, a nature the fixity of a score cannot support. Scape Plots emerge as a sort of text in and of themselves, one crucial to understanding performance histories and their traditions.

Each of Turandot's three primary roles—Liù, Calaf, and Turandot—requires its respective singers to communicate a dramatic arc of grand opera proportions through some of Puccini's most visceral, exhilarating, and heart-rending music. Through her temporal textual emphases, and with her manipulation of timbre, Andréa Gruber created a Turandot who is not merciless by her nature, but rather as a coping mechanism because she is a victim of her father's attempts to maintain power and control over her, as his age and infirmity increasingly inhibit his ability to do so to the people of Peking. For her, Calaf's arrival is a rescue, albeit one fraught with trepidation over the dual unknowns of a life outside her father's dominion and of being able to satisfy her latent and suppressed, yet still burgeoning sexuality. Similarly, Marcello Giordani created a Calaf who breaks the stereotype of a fin de siècle tenor as sexual predator. Instead, Giordani's temporal-textual emphases and resulting connections convey a hero who exudes an idealistic love marked by concern for all characters in Turandot's Peking, rather than one who is serving himself, or an autobiographical projection of Puccini's own womanizing.

By their very existence, each performance interpretation in Turandot's history at the Metropolitan Opera has contributed to this work's ongoing tradition at the USA's preeminent opera house. Future investigations using the methods that this study has developed could establish performance traditions at other preeminent opera houses around the world. Furthermore, a comparison of these performance traditions would generate a fuller understanding of how the producing companies have each presented unique versions of Turandot. Taken together, all performances enrich Turandot's existence, regardless of how audiences or critics respond to them. Performances of this, or any, opera, while connected by their being techne -in revealing a work as poiēsis - and the traditions they create, ultimately serve as testaments to the diversity and vibrancy of the human experience.

\section{Further Considerations}

This research forms a foundation for investigation of the expressive palette for both vocal and instrumental music. Future developments will build on current means of analyzing dynamics across a performance and refine or develop techniques for examinations of: pitch modulation (including vibrato, shading, and portamento), articulation, phrasing and breathing, timbre (including dark and light vowel sounds, and vocal quality color associations), and diction. Of course, these additional analyses will generate their own data sets, which in turn will be useful as ground truth or control sets for use in machine learning. By comparing the results of musical feature extraction algorithms against human curated data, more accurate algorithms are possible, thereby speeding up the data extraction and analysis processes. [28] Connecting empirical data describing musical phenomena of the opera stage, singers' unique dramatic interpretations, and critical theories of how the operatic art world and musical works operate does more than deliver a new methodology. Such a process ultimately offers one view into understanding how, even across time and place, as Friedrich Hölderlin observed, 'poetically dwells man upon this earth' (Heidegger, 1977, p. 34). 


\section{ACKNOWLEDGMENTS}

The author extends his gratitude to the staff of the Rodgers and Hammerstein Archive of Recorded Sound at the New York Public Library for their assistance in the archival research portion of this project. Additional thanks go to singers Marcello Giordani and Andréa Gruber for graciously granting interviews, to Margaret Butler, Mark Katz, Jennifer Thomas, and Alexandra Monchick for comments on early drafts of this work, and to the reviewers and editorial staff of Empirical Musicology Review. This article was copyedited by Scott Bannister and layout edited by Kelly Jakubowski.

\section{NOTES}

[1] Correspondence can be addressed to: Joshua Neumann, School of Music, University of Florida, PO Box 117900, Gainesville FL 32611, U.S.A.

[2] Here, I use producers and consumers in the same sense as Becker. Producers are those who are responsible for bringing any work of art to its audience and critics—-the consumers.

[3] See Neumann (2016a), particularly chapters 1, 4, 5, and 6 for empirical models of tradition and analysis thereof.

[4] (Campanari, 1906) 'A Lodi, a Crema, a Monza, potrebbero riprodurre La Traviata come in rappresenta ora alla Scala e di comprende [sic] come il pubblico di quei piccoli teatri andrebbe in folla ad udire, sia pure più o meno bene riprodotte, le abilità canore di artisti che mai avrebbero sognato di avere nelle loro città. $\mathrm{E}$ così si rinuncerebbe ad organizzare spettacoli relativamente costosi e che necessitano un certo prezzo d'ingresso, mentre col mezzo del cinematografo, il pubblico si divertirebbe spendendo solo venti e trenta centesimi. 'In Lodi, Crema, and Monza, they could reproduce La traviata as now staged at La Scala, and understand how the public of those small theaters would go in droves to hear, albeit more or less well reproduced, the singing skills of artists that they would never have dreamed of having in their cities. And in this way one would forgo organizing relatively expensive performances that require a certain entrance fee, while the public would be entertained by means of the cinema, spending only twenty or thirty centesimi.'

[5] This letter appears in Coppialettere 1905-1906, vol. 15, \#59. The volumes of Coppialettere hold archival copies of all out-going correspondence form the Ricordi main offices in Milan. 'Di conseguenza se la vostra Società crede di occuparsi di tutelare la esecuzione di pezzi di opere con fonografi che si possano dare in pubblico, lo faccia'

[6] 'Wesen' is notoriously problematic in translation. While acknowledging the normal translation, I have elected to leave this word untranslated as its meaning is far fuller than 'essence.' See Martin Heidegger (1977), for a seminal discourse on the topic.

[7] As Table 1 illustrates, lighting effects changed with the emergence of gaslight capabilities in theaters, and Thomas Edison emended his patent filing for motion picture to stipulate its primary use for preserving opera performances. (Schubin, 2011)

[8] Transcription of chart included in handout for Schubin’s 2011 lecture, used with permission.

[9] See Heidegger, 1977, p. 27. Heidegger characterizes 'coming into being' by using 'presences' in a verb form to reflect an internal impetus for this process rather than an external one. Alternatively, this can also reflect any internal aspects of any process by which what Heidegger terms 'revealing' or 'unconcealing' comes to pass.

[10] “. . . the word [written work] is called upon to mediate between past and present. . . Neither the being that the creating artist is for himself - call it his biography - nor that of whoever is performing the work, nor that of the spectator watching the play, has any legitimacy of its own in the face of the being [or the coming into being] of the artwork itself.” (Gadamer, 2014, p. 129) 
[11] I use opsicentrism to describe the view, advocated by Gadamer, that the performance is closer to the Heideggerian 'wesen' of the musical work than the score can ever be. While Gadamer's stance might at first seem a reactionary position to adopt, it bears consideration. With regard to musical meaning, and what actually the musical entity 'is,' the understanding of the meaning between what appears on paper and what one hears is of utmost pertinence.

[12] I have adopted Heidegger's word parsing in order to emphasize the semantic nuance of his etymology.

[13] See Nicholas Cook, Beyond the Score, and The Cambridge Companion to Recorded Music (Cambridge: Cambridge University Press, 2009); Nicholas Cook and Craig Sapp, 'Purely coincidental? Joyce Hatto and Chopin's Mazurkas,' http://www.charm.rhul.ac.uk/projects/p2_3_2.html; Tim Crawford and Lorna Gibson, eds. Modern Methods for Musicology: Projects, Proposals, and Realities (New York: Routledge, 2016); and Craig Sapp, 'Computational Methods for the Analysis of Musical Structure,' (PhD diss., Stanford University, 2011), http://purl.stanford.edu/br237mp4161; and 'Hybrid Numeric/Rank Similarity Metrics for Musical Performance Analysis' (Paper presented at the Ninth International Conference on Music Information Retrieval, Drexel University, Philadelphia, PA, September 14-18, 2008), http://ismir2008.ismir.net/papers/ISMIR2008_240.pdf. This list is only a partial sample, but one that represents methods inspiring the modes of analysis in this article.

[14] http://www.mazurka.org.uk/.

[15] See Luigi Ricci, Puccini: interprete di se stesso... Harry Dunstan, "Performance practices in the music of Giacomo Puccini as observed by Luigi Ricci, PhD diss., The Catholic University of America, 1989 is an English translation of Ricci's text.

[16] For cohesion and concision, the explanation of the analysis for each performed aria appears as a blended narrative rather than in a strict "data analysis-hypothesis-confirmation of results" format.

[17] All translations taken from Weaver (1981).

[18] Birgit Nilsson (1918 - 2005) was the preeminent Wagnerian soprano following Kirsten Flagstad's retirement in 1952 until her own retirement in 1982. Nilsson famously quipped that singing Richard Wagner's Isolde (Tristan und Isolde) made her famous and singing the titular role in Turandot made her rich. Nilsson's effect on Turandot at the Met is difficult to understate, as her willingness to sing the role led to the Met's revival of the opera in 1961 after its thirty-year absence due to the difficulty in finding a singer capable of performing the role. Nilsson appears in the accessible recorded performance history of Turandot at the Met more than any other soprano of the role. Her five appearances (of nineteen total recordings) equals that of tenor Franco Corelli (with whom she appears three times), and that of conductor Nello Santi (whose appearances postdate both Nilsson and Corelli). She appeared in fifty-two performances between 1961-1970, covering each year except 1964, when Turandot was not part of the Met’s season.

[19] See Neumann (2016a) chapter 3 and Appendix C for analysis of individual tempo hierarchies and further examples.

[20] Text from the final duet of the opera, taken from Puccini (2000), 429-36. 'Del primo pianto, sì, straniero, quando sei giunto, con angoscia ho sentito il brivido fatale di questo mal supremo...ma ho temuto te! C'era negli occhi tuoi la luce degli eroi!

[21] See Neumann (2016a), particularly Chapter 3 and Appendix D.

[22] As Table 2 illustrates, Calaf's text in this aria is primarily about ensuring ongoing care-giving for Timur should the prince fail in his attempt of Turandot's riddles.

[23] This was the first of several points in my interview where Giordani used the phrase "simile a Dio" to describe the kind of love he sees Calaf trying to show everyone he encounters throughout the plot. The second point in the opera where Giordani used this phrase was after successfully answering Turandot's riddles, when Calaf issues his riddle to the princess as a means of giving her a way out of marrying him. This riddle in turn 
sets up the dramatic impetus for the beginning of Act III and Calaf's reflection on Turandot's prohibition on sleeping in Peking until the Prince's named is discovered.

[24] See Neumann (2016a), particularly Chapter 3, for an analysis of Franco Corelli's performance on 04 March 1961.

[25] Understandably, this hierarchical structure depends largely on the imposed ordering of text and music by Puccini and his librettists, Adami and Simoni.

[26] My interview with Giordani frequently flipped between Italian and English. I have provided the English versions of his quotations. In describing Calaf at the point of "Nessun dorma!", early in Act III, Giordani explained that "Lui ama tutti, perchè a quest punto, lui è amore."

[27] If the overlap between the dramatic understandings of Calaf and Turandot between Gruber and Giordani seems substantial, that they have sung the opera together on numerous occasions might be one explanation. Obviously, additional investigation is of course necessary to reach any hypotheses or conclusions about influence.

[28] Data from this project is available upon request to potential partners affiliated with the Music Information Retrieval Evaluation eXchange (MIREX) at the University of Illinois, the Center for Computer Assisted Research in the Humanities (CCARH) at Stanford University, the Oxford e-Research Centre, the Semantic Media Network, and others.

\section{REFERENCES}

Barthes, R. (1990). Image-Music-Text. (Stephen Heath, Trans.). New York, NY: Noonday Press.

Becker, H. (1982). Art Worlds. Berkeley, CA: University of California Press.

Campanari, U. (1906, February 27). Libro delle sedute del Consiglio di Vigilanza 1900-1940.

Clarke, E. (2012). Creativity in performance. In D. Hargreaves, D Miell, \& R. MacDonald (Eds.), Musical Imaginations: Multidisciplinary perspectives on creativity, performance, and perception (pp. 17-30). Oxford: Oxford University Press.

Cook, N. (2013). Beyond the Score: Music as Performance. Oxford: Oxford University Press.

Cook, N., Clarke, E., Leech-Wilkinson, D., \& Rink, J. (2009). The Cambridge Companion to Recorded Music. Cambridge: Cambridge University Press. https://doi.org/10.1017/CCOL9780521865821

Cook, N. \& Sapp, C. (2006). Purely coincidental? Joyce Hatto and Chopin's Mazurkas. Retrieved from http://www.charm.rhul.ac.uk/projects/p2_3_2.html.

Crawford, T. \& Gibson, L. (Eds.). (2016). Modern Methods for Musicology: Projects, Proposals, and Realities. New York: Routledge.

Derrida, J. (1974). Of Grammatology. (Gayatri Chakravorty Spivak, Trans.). Baltimore, MD: The Johns Hopkins University Press.

Durante, S. (1998). 'The Opera Singer.' In Lorenzo Bianconi and Giorgio Pestelli (Eds.), Opera Production and Its Resources. Chicago: The University of Chicago Press.

Eaglestone, R. (2013). Contemporary Fiction: A Very Short Introduction. Oxford: Oxford University Press. https://doi.org/10.1093/actrade/9780199609260.001.0001

Gadamer, H. G. (2014). Truth and Method. London: Bloomsbury Academic.

Giordani, M. (2013, July 11). Interview with the author, Torre del Lago Puccini, Tuscany, Italy. 
Gruber, A. (2015, January 29). Interview with the author. New York, NY.

Heidegger, M. (1977). The Question Concerning Technology and Other Essays. (William Lovitt, Trans.). New York, NY: Harper Perennial.

Leech-Wilkinson, D. (2007). Sound and meaning in recordings of Schubert's 'Die junge Nonne,' Musicae Scientiae, 11(2), 209-36. https://doi.org/10.1177/102986490701100204

Neumann, J. (2016a). Toward Defining Tradition: A Statistical and Network Analysis of Giacomo Puccini's 'Turandot' at the Metropolitan Opera (Unpublished doctoral dissertation). University of Florida, Gainesville, FL.

Neumann, J. (2016b). Data generation and multimodal analysis for recorded operatic performance. In B. Fields \& K. Page (Eds.), DLfM 2016: 3rd International Workshop on Digital Libraries for Musicology (pp. 49-52), New York, USA. https://doi.org/10.1145/2970044

Puccini, G. (2005, January 29). Turandot [Compact disc]. New York, NY: Metropolitan Opera. (Available from Rodgers and Hammerstein Archive of Recorded Sound, New York Public Library for the Performing Arts, Dorothy and Lewis B. Cullman Center, 40 Lincoln Center Plaza, New York, NY, 10023).

Puccini, G., Adami, G., Simoni, R., \& Alfano, F. (2000). Turandot: Dramma lirico in tre atti e cinque quadri. Milano: Ricordi.

Puccini, G., Zeffirelli, F., Nelsons, A., \& Metropolitan Opera Orchestra \& Chorus. (2011, November 07). Turandot: Opera in three acts. London: Decca.

Ricordi, G. (1906, March 23). Letter to the Società Italiana degli Autori. Coppialettere 1905-1906, 15(59).

Rink, J. (2002). Analysis and (or?) performance. In J. Rink (Ed.), Musical Performance: A Guide to Understanding (pp. 35-58). Cambridge: Cambridge University Press. https://doi.org/10.1017/CBO9780511811739.004

Sapp, C. (2008, September). Hybrid Numeric/Rank Similarity Metrics for Musical Performance Analysis. Paper presented at the Ninth International Conference on Music Information Retrieval, Drexel University, Philadelphia, PA. Retrieved from http://ismir2008.ismir.net/papers/ISMIR2008_240.pdf.

Sapp, C. (2011). Computational Methods for Analyzing Musical Structure (Doctoral dissertation). Retrieved from http://purl.stanford.edu/br237mp4161.

Schubin, M. (2011, October 6). The Fandom of the Opera: How Opera Helped Create the Modern Media World. Lecture presentation at the Library of Congress, Washington, D.C.

Thomas, C. (2015, July). When Opera Met Film: Casa Ricordi and the Emergence of Cinema. Paper presented at the First Transnational Opera Studies Conference, Bologna, Emilia-Romagna, Italy.

Weaver, W. (1981). Seven Puccini Librettos. New York: W.W. Norton \& Company, Inc. 